\title{
The Evaluation of Supply Chain for Information System in GELAEL Supermarket at Semarang Indonesia
}

\author{
Abdulmunem Bireedan \\ Magister of Information System \\ Diponegoro University
}

\author{
Suryono \\ Magister of Information System \\ Diponegoro University
}

\author{
Jatmiko Endro Suseno \\ Magister of Information System \\ Diponegoro University
}

\begin{abstract}
The information system is a system within an organization reconcile the needs of the processing of daily transactions, support the operation, managerial and strategic activities of an organization and provide outside parties certain reports required. A supply chain refers to a complex network of relationships that sustain the organization with business partners to source production in conveying to the consumer. A supply chain management is very important for a company to make better effectiveness. Aim of this study was to developed information system to evaluate supply chain in supermarket. The tools that used in this research was the design of safety stock evaluation programs. The material was the supermarket and the data of safety stock, data of inventory each products, data of suppliers, and data of warehousing. The tool used in this research were PHP and My SQL. The sample is 15 respondents as staff in supermarket in Semarang Indonesia. The method analysis use in this research is descriptive analysis. The result of this study generate database system that can manage company data and avoid duplication of data. In this research produce inventory application which has product feature, supplier, inventory, transaction, and data warehous. The information system in supply chain at Gelael supermarket is very useful to know safety stock of product and avoid stock out product. New findings/significance that the design of this information system can help staff to work more efficiently and effectively in knowing the safety stock of products and overcome the product stock out.
\end{abstract}

\section{General Terms}

Design of Safety Stock

\section{Keywords}

supply chain, information system, supermarket

\section{INTRODUCTION}

The information system can also be defined technically as a set of interrelated components that collect (or retrieve), process, store, and distribute information to support decision making and control within the organization[1].

The system is a combination of information can be organized in any of those people, hardware, software, network communications and resource data collected. People rely on information systems to communicate between each other using various types of physical tools (hardware), the command and information processing procedures (software), communication channels (networks), and the stored data [2].

Conducted a study on enterprise resource planning: implementation procedures and critical success factors. This study appreciated the complex nature of ERP systems. He pointed out that implementation of ERP is costly and demands a lot of organizational time and resources [3]. Sought to establish the critical factors in the implementation of ERP and identified seven factors; business plan and vision, change management, communication, ERP team composition, skills and compensation, management support and championship, project management skills, system analysis, selection and technical implementation skills[4].

This chain is also a network of organizations that are interconnected and share the same goal, which is the best possible procurement or dealer hold the item [5].

\section{RELATED WORK}

Some previous studies that related to supply chain management, was to find out the effect of Information Systems on Upstream Supply Chain Management. It determined the effect of ERO on Upstream Supply Chain Management and the effect of EDI on Upstream Supply Chain Management among supermarkets with in Nakuru town. This study involved all the 9 supermarkets in Nakuru town. The recommended that organizations, especially fast moving inventory should take a strategic approach to adoption of information systems concerned with supply chain management[6]. They also concluded that the implementation of Supply Chain Management Software involves expensive alterations and customizations in the organization and therefore organizations have to be strategic in adopting these systems. They further suggested further research on the potential benefits and problems of using supply chain management software [7].

\section{RESEARCH METHODOLOGY}

\subsection{Material and Tool}

In this research, the sample is data about safety stock and factors affecting safety stocks in supermarket and the questionnaires will be spread on the sample is 15 respondents as staff in supermarket in Semarang. The tools that used in this research is the design of safety stock evaluation programs. The material is the supermarket and the data of safety stock, data of inventory each products, data of suppliers, and data of warehousing. The tool used in this research are PHP and My SQL.

\subsection{Research Procedure}

In this research there are some steps of the study, such as: Planning and identification problem

Planning is about the evaluation of safety stock in supermarket.

The identification problem is about the difficulty of safety stock calculation in supermarket.

Make the program of evaluation supply chain in supermarket. The program will used PHP and My SQL and the data containing the data inventory or stock, data of products, data inventory, data suppliers and data warehousing. 


\subsection{System Framework}

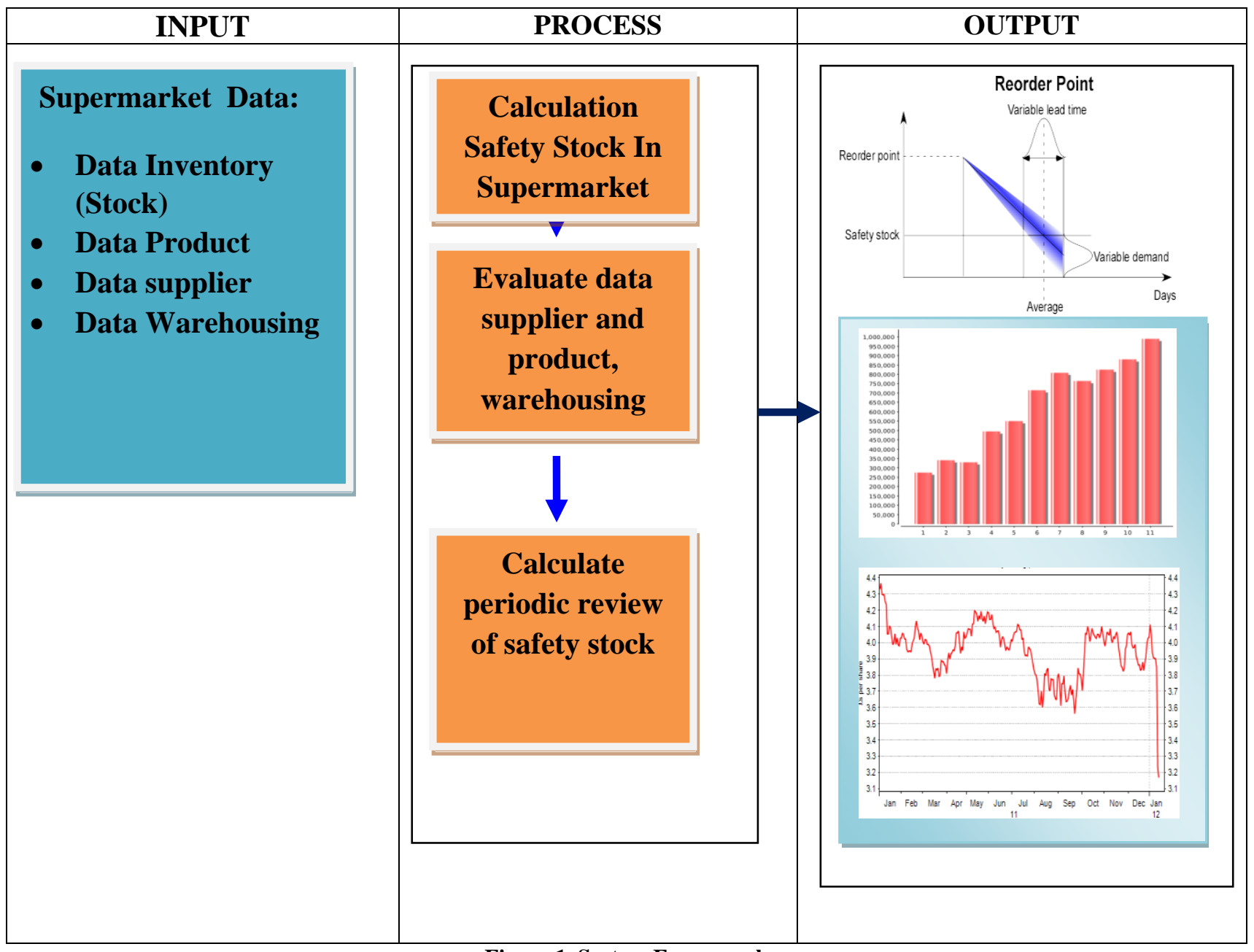

Figure 1. System Framework

\section{RESULT}

\subsection{Design Information System in Supply Chain Supermarket}

Information systems and supply chains have a strategic role to build and enhance the company's ongoing competitive advantage. Here is the design of information systems used in the supply chain at Gelael supermarket.

Home, in this menu contain of logged in user as admin (Figure.2).

Management data, in this menu contain:

Product, in this menu contains the product data. In the product data there are all the product of the supermarket (Figure .3). Supplier, in this menu contains the name of the supplier of the supermarket (Figure .4).
Inventory, in this menu contains the name of the supplier, name of the

product, a number of the stocks, and date add the information (Figure .5).

Transaction, in this menu contains the name of the supplier, name of the product, recorder point, average usage, safety stock, quantity, and year (Figure .6).

Data Warehouse, in this menu contains the name of the product, total recorder point, jumlah, month, and year (Figure .7).

Dashboard, in this menu contains the name of the supplier and year to show the graph of safety stock the supply chain and real time supply chain management (Figure.8, and Figure.9) . 


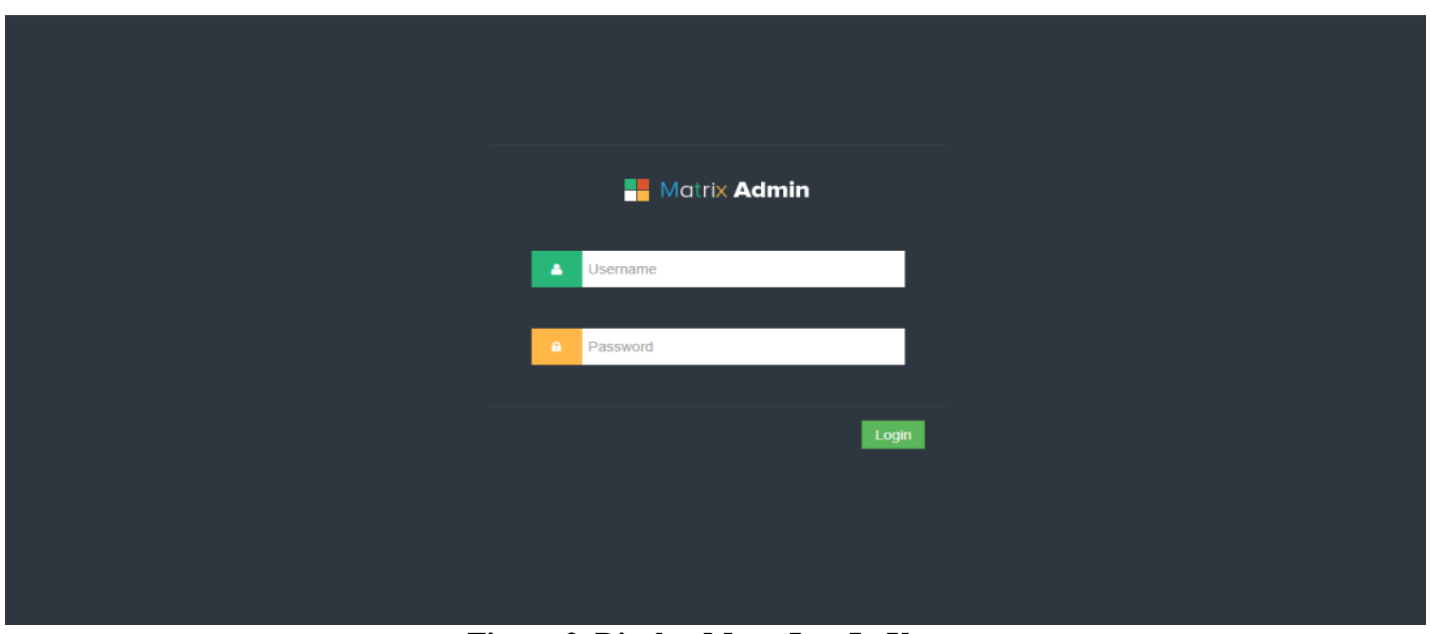

Figure 2. Display Menu Log In User

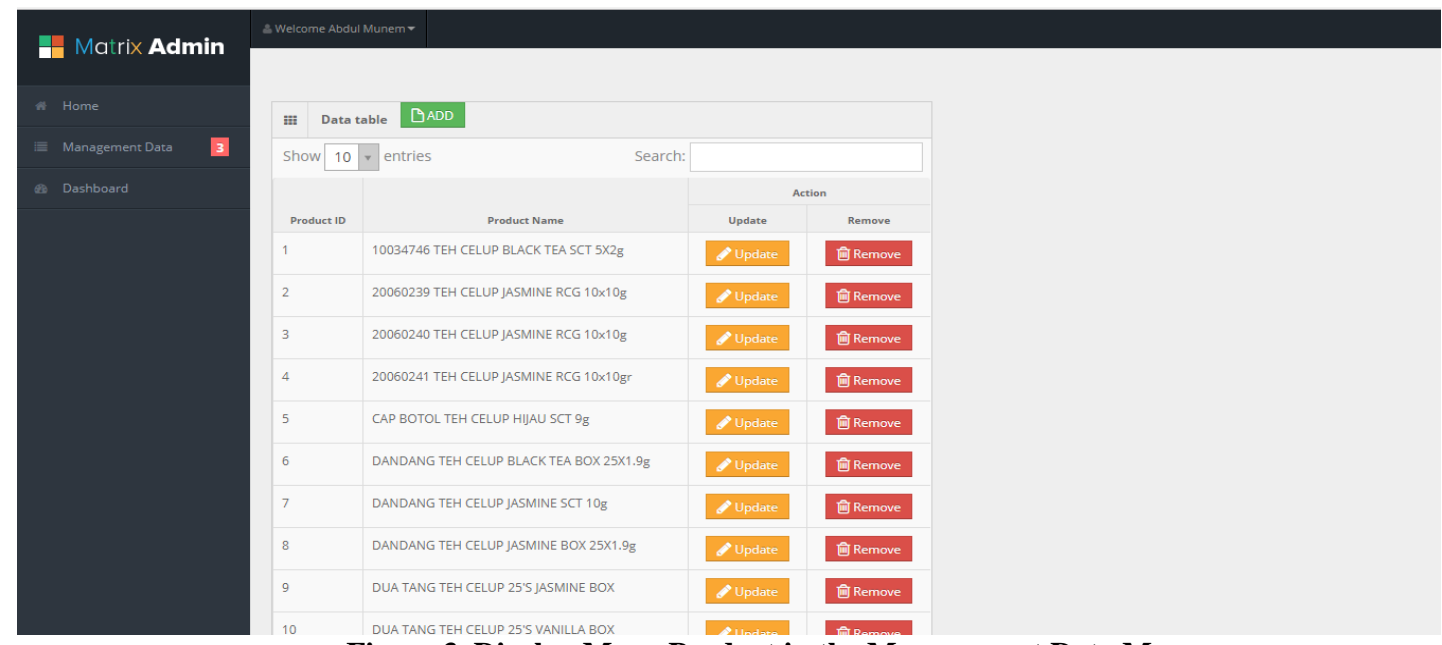

Figure 3. Display Menu Product in the Management Data Menu

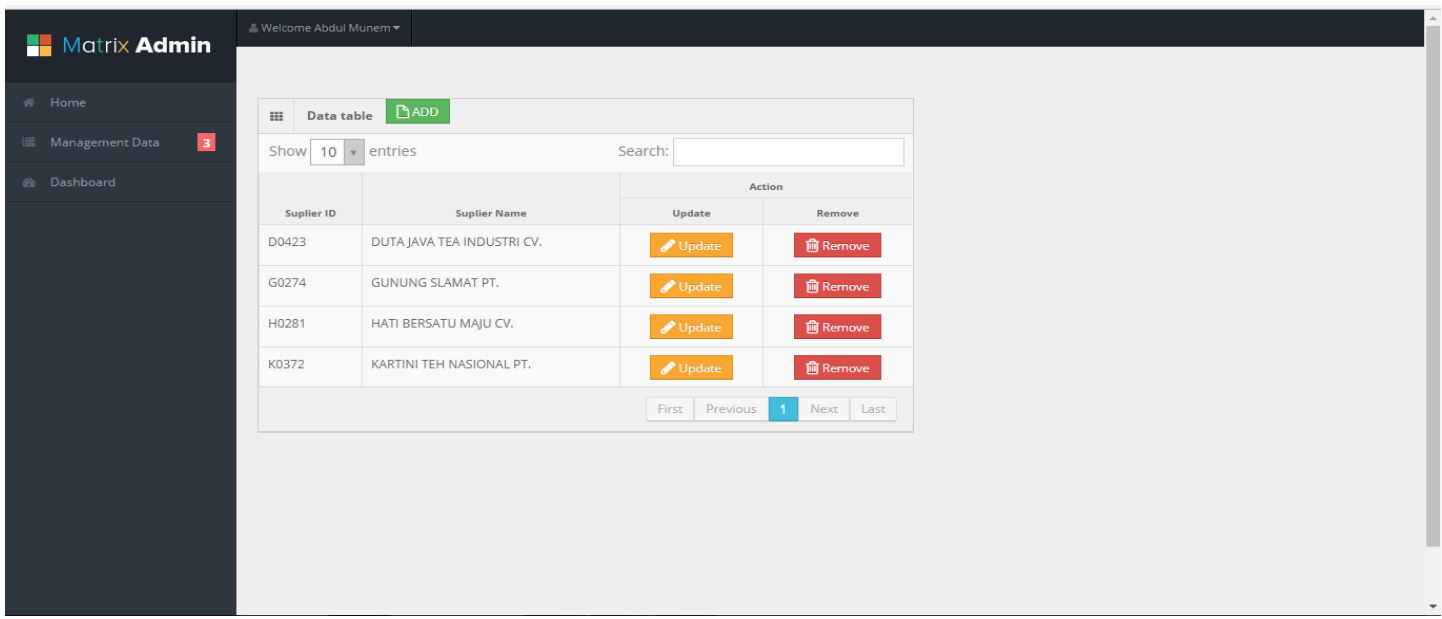

Figure 4. Display Menu Supplier in the Management Data Me 


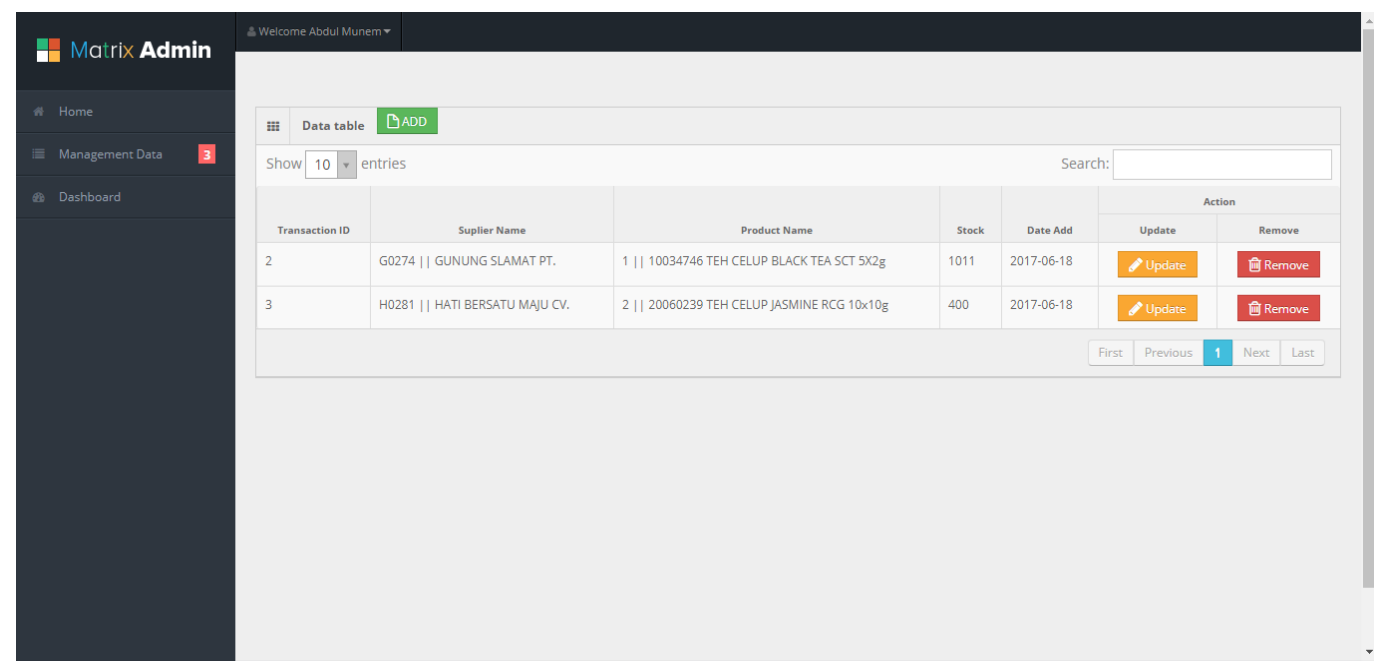

Figure 4. Display Menu Inventory in the Management Data Menu

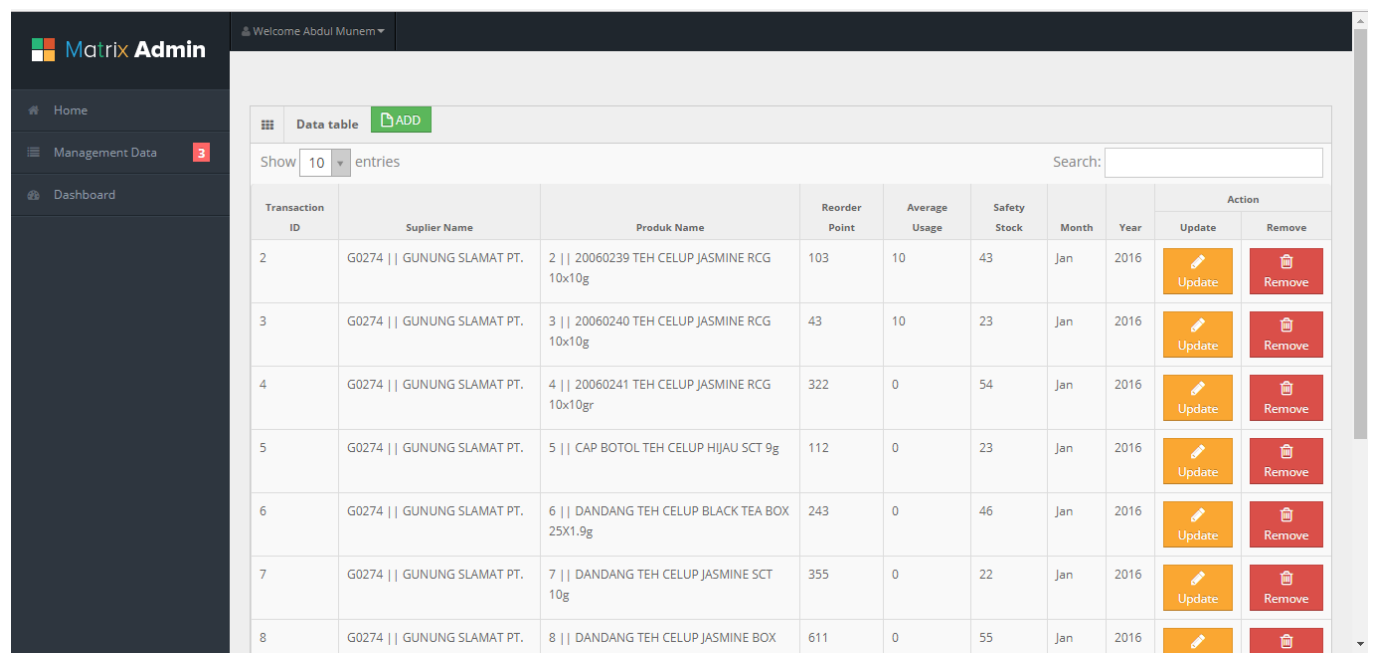

Figure 5. Display Menu Transaction in the Management Data Menu

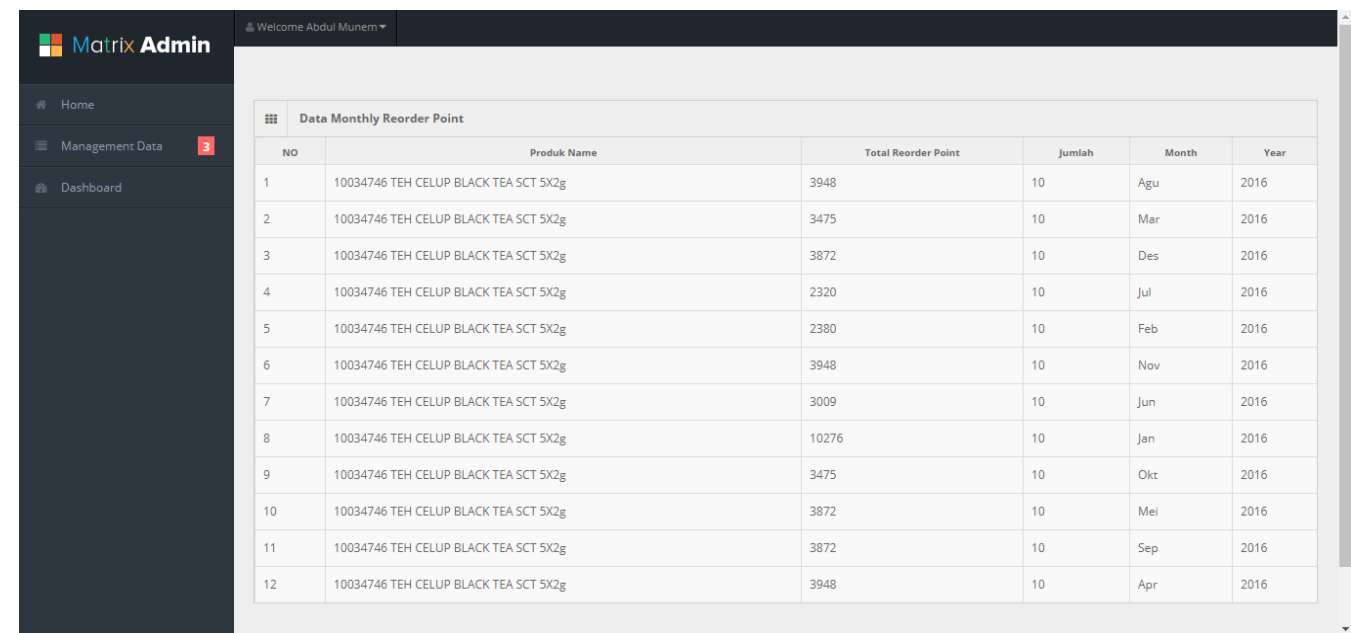

Figure 6. Display Menu Datawarehouse in the Management Data Menu 


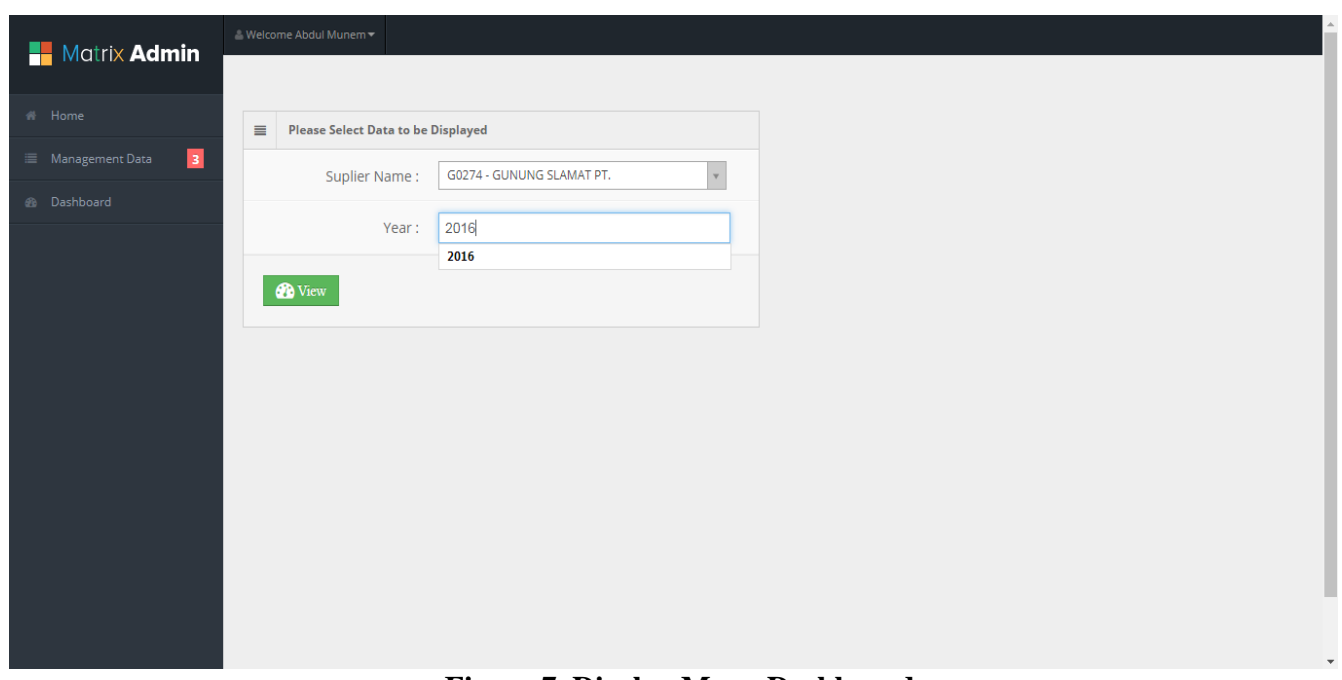

Figure 7. Display Menu Dashboard

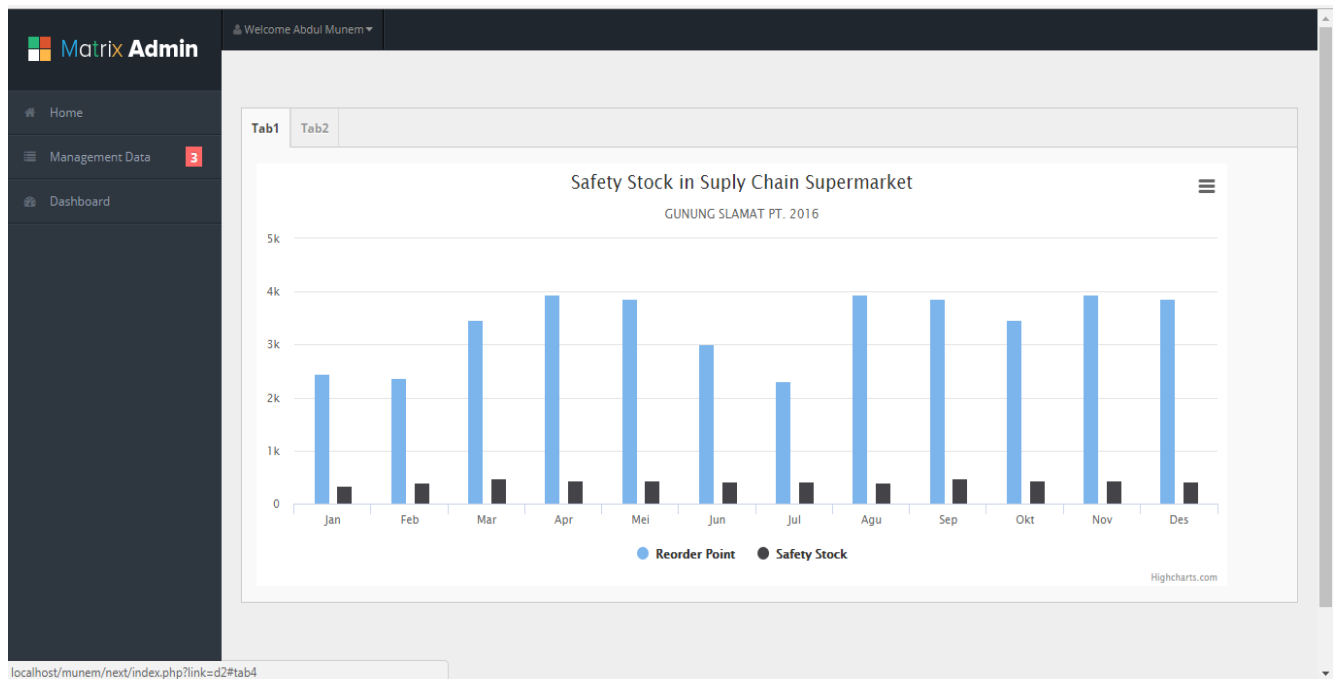

Figure 7. Display Output Recorder Point and Safety Stock

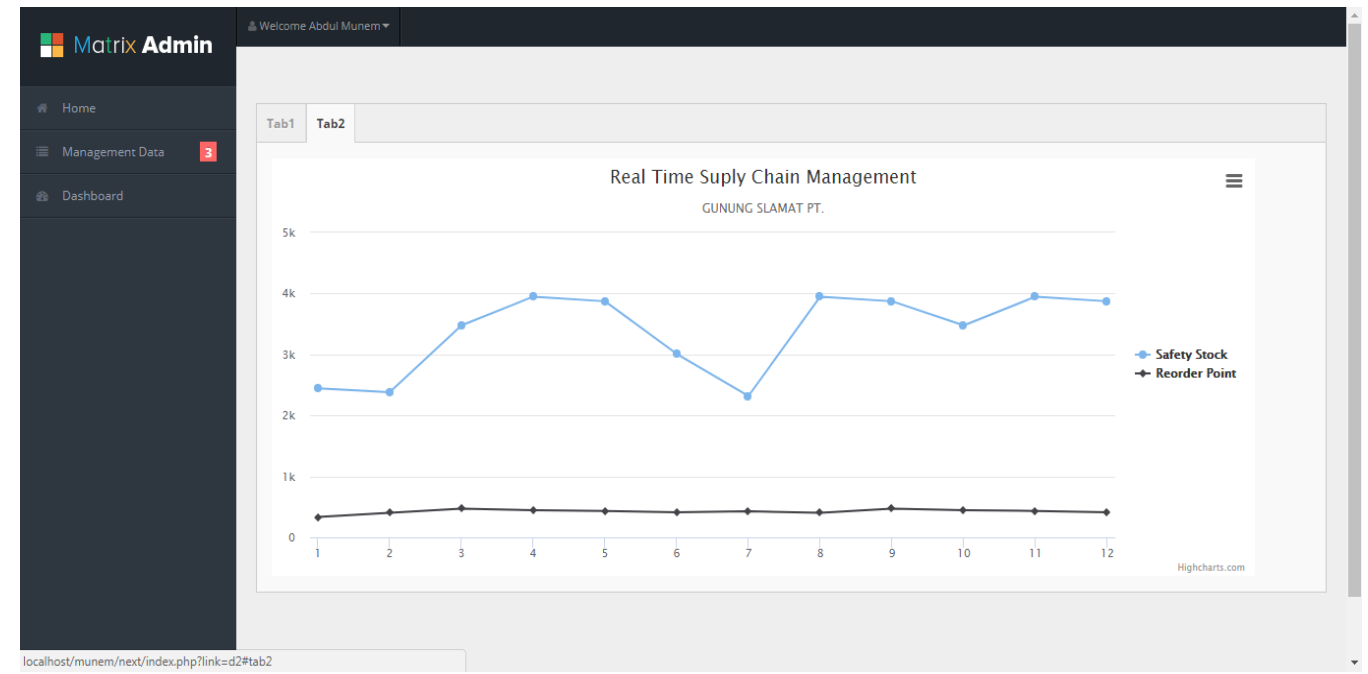

Figure 8. Display Output Real Time 


\subsection{Evaluation Information System in Supply Chain Supermarket}

\subsection{Gender}

Data of respondents characteristic based on the gender served in the table 4.1:

Table 4.1 Gender of Respondent

\begin{tabular}{lll}
\hline Gender & $\mathrm{N}$ & Frequency $(\%)$ \\
\hline Male & 7 & 46.7 \\
Female & 8 & 53.3 \\
\hline Total & 15 & 100
\end{tabular}

Table 4.1presents the number of male respondents is 7 respondents or $46.7 \%$ whereas the female respondents is 8respondents about $53.3 \%$ of the populations. Thus the most number of respondents is female respondents with the number of 8 persons or $53.3 \%$.

Table 4.2 Age of Respondent

\begin{tabular}{lll}
\hline Age (years old) & $\mathrm{N}$ & Frequency (\%) \\
\hline$<21$ & 2 & 13.3 \\
$21-25$ & 1 & 6.7 \\
$26-30$ & 6 & 40.0 \\
$31-35$ & 1 & 6.7 \\
$36-40$ & 2 & 13.3 \\
$>41$ & 3 & 20.0 \\
\hline Total & 15 & 100.0 \\
\hline
\end{tabular}

\subsection{Description Analysis}

Evaluation of information system in the supply chain supermarketis done using descriptions of data from questionnaires that are asked to the staff of the supermarket. Table 4.3 is a description of data from the respondent's answer.

Table 4.3 Description Data of Variables

\begin{tabular}{|l|l|l|l|l|}
\hline \multirow{2}{*}{ Indicator } & \multicolumn{3}{|l|}{ Data Description } \\
\cline { 2 - 5 } & Mean & Max & Min & Mode \\
\hline $\begin{array}{l}\text { The design of this } \\
\text { information system is } \\
\text { easy to use and } \\
\text { understand }\end{array}$ & 3.80 & 4 & 3 & 4 \\
\hline $\begin{array}{l}\text { The menus of this } \\
\text { information system are } \\
\text { easy to use and } \\
\text { understand ond this }\end{array}$ & 3.73 & 5 & 3 & 4 \\
\hline $\begin{array}{l}\text { The design of } \\
\text { information system } \\
\text { makes the job easier }\end{array}$ & & 5 & 3 & 4 \\
\hline $\begin{array}{l}\text { The design of this } \\
\text { information system is } \\
\text { able to provide useful } \\
\text { information to know the }\end{array}$ & 3.47 & 4 & 3 & 3 \\
\hline
\end{tabular}

\begin{tabular}{|c|c|c|c|c|}
\hline $\begin{array}{l}\begin{array}{l}\text { condition of product } \\
\text { stock }\end{array} \\
\end{array}$ & & & & \\
\hline $\begin{array}{l}\text { The design of this } \\
\text { information system is } \\
\text { able to provide } \\
\text { information about safety } \\
\text { stock }\end{array}$ & 3.53 & 4 & 3 & 4 \\
\hline $\begin{array}{l}\text { The design of this } \\
\text { information system can } \\
\text { reduce the risk of stock } \\
\text { out }\end{array}$ & 3.80 & 4 & 3 & 4 \\
\hline $\begin{array}{l}\text { The design of this } \\
\text { information system is } \\
\text { able to provide } \\
\text { information about lead } \\
\text { time }\end{array}$ & 3.73 & 4 & 3 & 4 \\
\hline $\begin{array}{l}\text { The design of this } \\
\text { information system } \\
\text { makes the work more } \\
\text { efficient }\end{array}$ & 3.67 & 5 & 1 & 4 \\
\hline $\begin{array}{l}\text { This information system } \\
\text { is able to provide policy } \\
\text { to the company regarding } \\
\text { product stock policy }\end{array}$ & 3.60 & 4 & 2 & 4 \\
\hline Summary & 3.67 & 5 & 1 & 4 \\
\hline
\end{tabular}

Based on the description of the data (table 4.3) it can be seen that the summary answer of the questionnaire is known that the answer of the maximum respondent is 5 and the minimum is 1 whereas the mode or answer that often appears is 4 that means agree.

\section{CONCLUSION}

Based on the results of the research can be concluded that: In this research generate database system that can manage company data and avoid duplication of data. Produce inventory application which has product feature, supplier, inventory, transaction, and data warehouse. The information system in supply chain at Gelael supermarket is very useful to know safety stock of product and avoid stock out product. Based on the respondent's answer, it is known that the design of this information system can help staff to work more efficiently and effectively in knowing the safety stock of products and overcome the product stock out.

\section{SUGGESTION}

Need to test the use of information systems directly to more known the shortcomings and advantages of this information system directly.

\section{REFERENCES}

[1] Laudon, K. C dan Jane P. L. 2017. Information Management. Jakarta: SalembaEmpat.

[2] O'Brien, J. A. 2015. Introduction to Information Systems. Jakarta: Salemba Empat.

[3] Umble, E. J., Haft, R. R. and Umble, M. M. 2013. Enterprise resource planning: Implementation procedures and critical success factors. European Journal of Operational Research 146 (2003)241-25.

[4] Fui-Hoonnah, F. and Delgado, S. 2016. Critical Success Factors for Enterprise Resource Planning Implementation and Upgrade. 
International Journal of Computer Applications (0975 - 8887)

Volume 179 - No.1, December 2017

[5] Indrajit, R.E. and Djokopranoto, R. 2015. Modern Higher Education Management. Yogyakarta: Andi Offset.

[6] Mundia, C., Elton K.L., and Steve L. 2015. Effect of Information System on Upstream Supply Chain Management Among Supermarkets in Nakuru Town, Kenya. International
Journal of Economics, Finance and Management Sciences; 3(5): 535-540.

[7] Buxmann, P., Ahsen, A., Díaz, L. M. \& Wolf, K. 2014. Usage and evaluation of Supply Chain Management Software: results of an empirical study in the European automotive industry. Info Systems Journal, 14, 295-309. 